\title{
Archaeological Survey of the North Salado Greenway Belt, San Antonio, Bexar County, Texas
}

Antonia L. Figueroa

Center for Archeological Research, University of Texas at San Antonio

Kristi M. Ulrich

Follow this and additional works at: https://scholarworks.sfasu.edu/ita

Part of the American Material Culture Commons, Archaeological Anthropology Commons, Environmental Studies Commons, Other American Studies Commons, Other Arts and Humanities Commons, Other History of Art, Architecture, and Archaeology Commons, and the United States History Commons

Tell us how this article helped you.

This Article is brought to you for free and open access by the Center for Regional Heritage Research at SFA ScholarWorks. It has been accepted for inclusion in Index of Texas Archaeology: Open Access Gray Literature from the Lone Star State by an authorized editor of SFA ScholarWorks. For more information, please contact cdsscholarworks@sfasu.edu. 


\section{Archaeological Survey of the North Salado Greenway Belt, San Antonio, Bexar County, Texas}

\section{Creative Commons License}

\section{(c) (1) (8)}

This work is licensed under a Creative Commons Attribution-NonCommercial 4.0 International License 


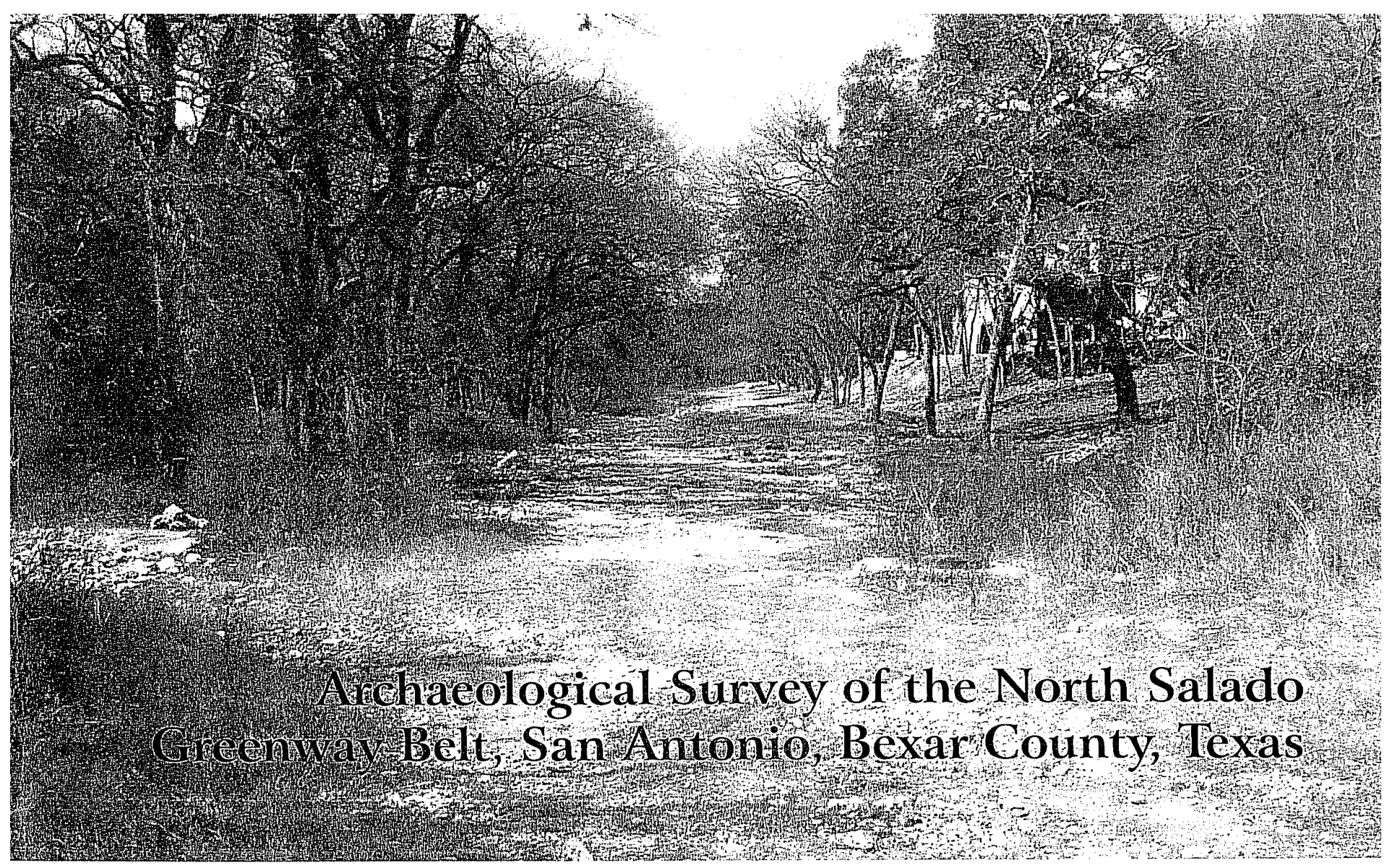

\section{by \\ Antonia L. Figueroa and \\ Kristi M. Ulrich}

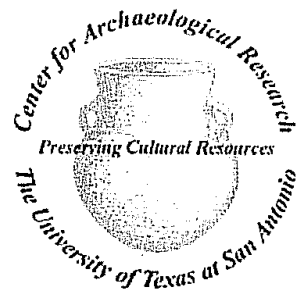

(C)2006

Archaeological Report, No. 367

Center for Archaeological Research

The University of Texas at San Antonio 


\section{Table of Contents}

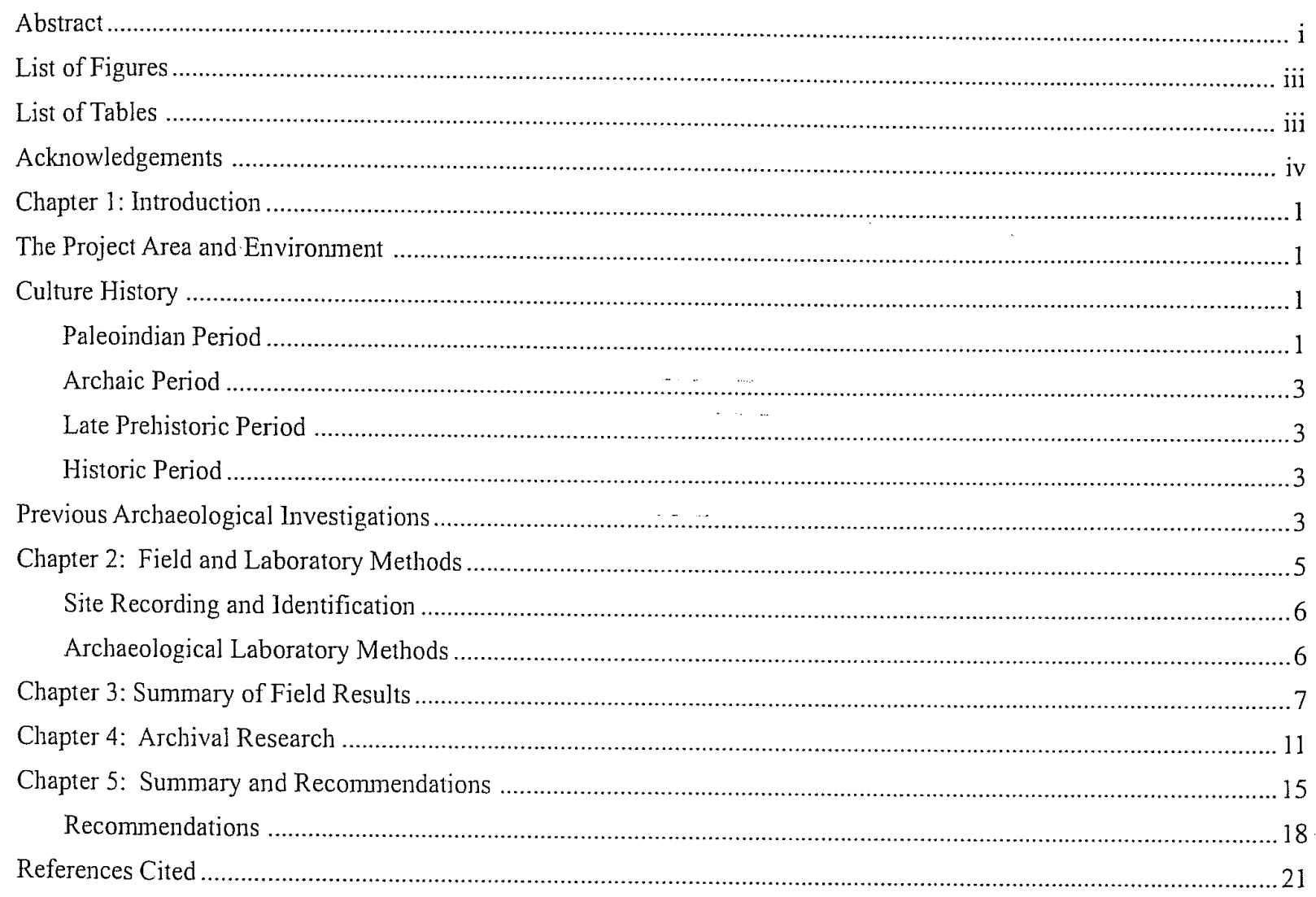




\section{Abstract}

A pedestrian survey was conducted in March and May of 2006 along a portion of Salado Creek located between Blanco Road and Huebner Road in the northern part of San Antonio. The Center for Archaeological Research of The University of Texas at San Antonio, in conjunction with volunteers from the South Texas Archeological Association, carried out the survey to fulfill the requirements of the contract with Rehler Vaughn and Koone, Inc., of San Antonio. The work was conducted in advanced of construction of hike and bike trails proposed by the Parks and Recreation Department of the City of San Antonio. Survey and shovel tests were utilized to search for historic properties within the Area of Potential Effect. Two new archaeological sites were recorded: a multicomponent site with a possible historic grave and prehistoric lithic scatter (41BX1656), and a prehistoric site consisting of lithic debitage and burned rock (41BX1657).

The fieldwork was conducted under Texas Antiquities Permit No. 4058 and Dr. Steve Tomka served as Principle Investigator. All artifacts collected were processed and pemnánently curated at the Center for Archaeological Research. 


\section{List of Figures}

Figure 1-1. The location of the project area on the Castle Hills 7.5-minute series USGS quadrangle map.....................2

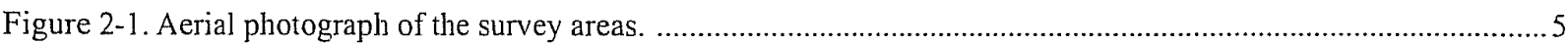

Figure 3-1. Aerial photograph showing the locations of shovel tests. ................................................................... 9

Figure 4-1. Aerial photograph of the Voelker Ranch property. ............................................................................. 11

Figure 4-2. Map showing the Thompson (No. 84), Caldwell (No. 83) and Dobie Surveys (No. 79), and the project area

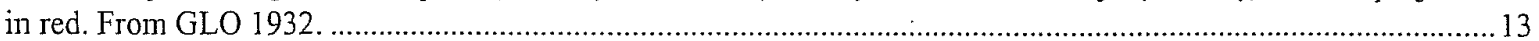

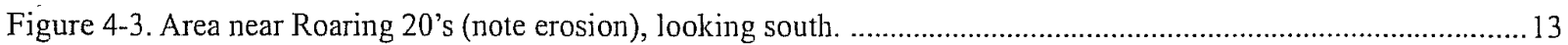

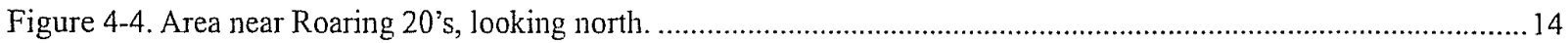

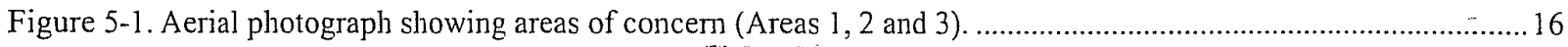

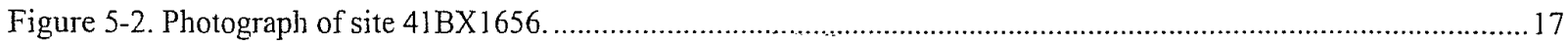

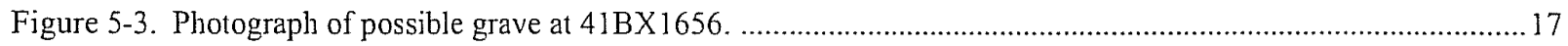

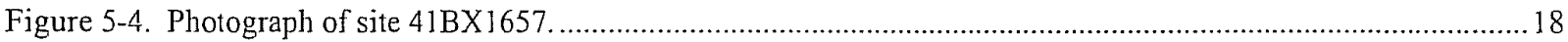

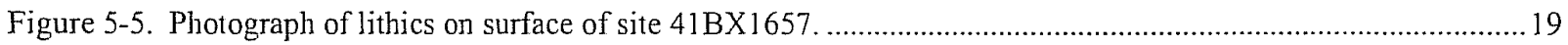

\section{List of Tables}

Table 3-1. Termination Depths and Presence/Absence of Artifacts for Shovel Tests ................................................... 7

Table 3-2. Historic Artifacts Recovered from North Salado Creek Shovel Tests ...................................................... 8 


\section{Acknowledgments}

The authors would like to extend their thanks to the individuals who aided in the success of this project. The Center for Archaeological Research would like to thank the volunteers from the South Texas Archaeological Association (STAA) who assisted in the survey and shovel testing of the Salado Creek Greenway Belt Project. The volunteers include: David Calame, Debbie Calame, Charles Calame, Savannah Calame, Joseph Beavin, Tom Weir, Barney Haegelin, Lyle Edwards, Tom Phillip, Paul Snith and Margaret Greco. The authors would especially like to thank Anne Fox and I. Wayne Cox (though he is no longer with us, he still provides us with much needed information), for their previous archival research of the surrounding area. We would also like to express our thanks to Kay Hindes of the City of San Antonio's Historic Preservation Office for her coordination of the STAA involvement. Special thanks to Cheryl Hicks of Rehler Vaughn and Koone, Inc. (RVK) for keeping us informed of the status of the project with weekly reports. Thank you to Kimberly Wolf, also of RVK, for her assistance in contractual matters and coordination. Thanks also to Paul K. Johnson, Project Manager of the Park Project Services, who assisted with gaining right-of-entry to the private properties located at the southern edge of the project area.

The field crew consisted of Leonard Kemp, and Dr. Steve Tomka served as Principle Investigator. Kristi Ulrich served as Project Archaeologist. Special thanks to Bruce Moses and Rick Young for the preparation of maps and final graphics for the report. The authors would also like" to thank Dr. Steve Tomka for his guidance and support during the course of the project. 


\section{Chapter 1: Introduction}

In March of 2006 The Center for Archaeological Research (CAR) of The University of Texas San Antonio conducted a 100 percent archaeological pedestrian survey for the proposed North Salado Creek Greenway Belt project located in north-central San Antonio, Bexar County, Texas. CAR was contracted by Rehler Vaughn and Koone, Inc., of San Antonio. The principal goal of the pedestrian survey was to identify and document all prehistoric and/or historic archaeological sites that may be impacted by the proposed improvements within the Area of Potential Effect (APE). The project consists of the development a multi-use greenway trail running from Huebner Road to Blanco Road along the Salado Creek channel. The proposed project is part of the City's long-range plan to maintain, improve, and expand existing multi-use greenway trails within the City. of San Antonio. These investigations were conducted under Texas Antiquities Permit No. 4058 with Dr. Steve Tomka serving as the Principal Investigator. This report will discuss the results of the archaeological pedestrian survey and archival research conducted on the North Salado Creek Greenway Belt project.

\section{The Project Area and Environment}

The project area is in north-central San Antonio between Huebner and Blanco Roads, with West Bitters to the northeast and NW Military Highway to the southwest (Figure 1-1). The confluence of Panther Springs Creek with Salado Creek is less than a mile southeast of the project area. The project area proper represents a linear stream channel and its immediately adjacent floodplain and low-lying terrace deposits. The project area measures approximately 85 acres and in many areas runs between continually expanding residential neighborhoods that are slowly encroaching on the already narrow streambed. The Right-of-Way (ROW) is an average of $150 \mathrm{~m}$ in width, and varies in different locations of the project area.

The immediate project area is within the Upper Salado watershed (Potter et al. 1995). The northern portion of the APE is defined by the steep and pronounced portion of the Salado Creek channel, while in the southern portion of the APE the channel is less defined. The project area is immediately north of what Potter et. al. (1995:10) describes as the Middle Salado. The Middle Salado has a significant decrease in the stream gradient as compared to the Upper Salado. Within the project area, there at least two ephemeral drainages that flow into the Salado Creek. The project area is located along the southern border of the Edwards Plateau where the Upper Salado drains the Balcones Cayonlands (Potter et al. 1995). Vegetation in the area appears to be secondary growth as a result of clearing due to residential development and possible historic cultivation.

The soils in the immediate vicinity of the active channel are described as frequently flooded Trinity and Frio Soils (Tf) (Taylor et al. 1991). Outside of the active channel, the soils on the edges of the project area are identified as Lewisville silty clays (Lv) and Patrick soils (Pa). A small segment of the soils near the southeastern end of the project area and another small portion near the northeastern end are identified as part of the Tarrant association ( $\mathrm{TaC}$ ). This area is characterized by gently undulating soils overlying shallow bedrock. Overall, the soils are relatively thin and represent a mixture of clay and stony matrix (Taylor et al. 1991: Sheets 21 and 22).

\section{Culture History}

The culture history of the region, in particular Bexar County, spans nearly 11,500 years. There are four periods that are discernible by changes in hunting and gathering technologies and material culture: Paleoindian, Archaic, Late Prehistoric and Historic. Discussions of the culture history as summarized in previous investigations within the environs of the Upper Salado watershed were consulted in order to give a brief overview for the purposes of this report (Black and McGraw 1985; Cliff et al. 1990; Weston 2003).

\section{Paleoindian Period}

The earliest culture period for the region is the Paleoindian period, which spans roughly from ca.10,000 B.C. to 7000 B.C. It is further divided into Early and Late Paleoindian. Material culture from early Paleoindian is characterized by Clovis and Folsom fluted projectile points utilized in hunting of megafauna. Unfluted points, such as 


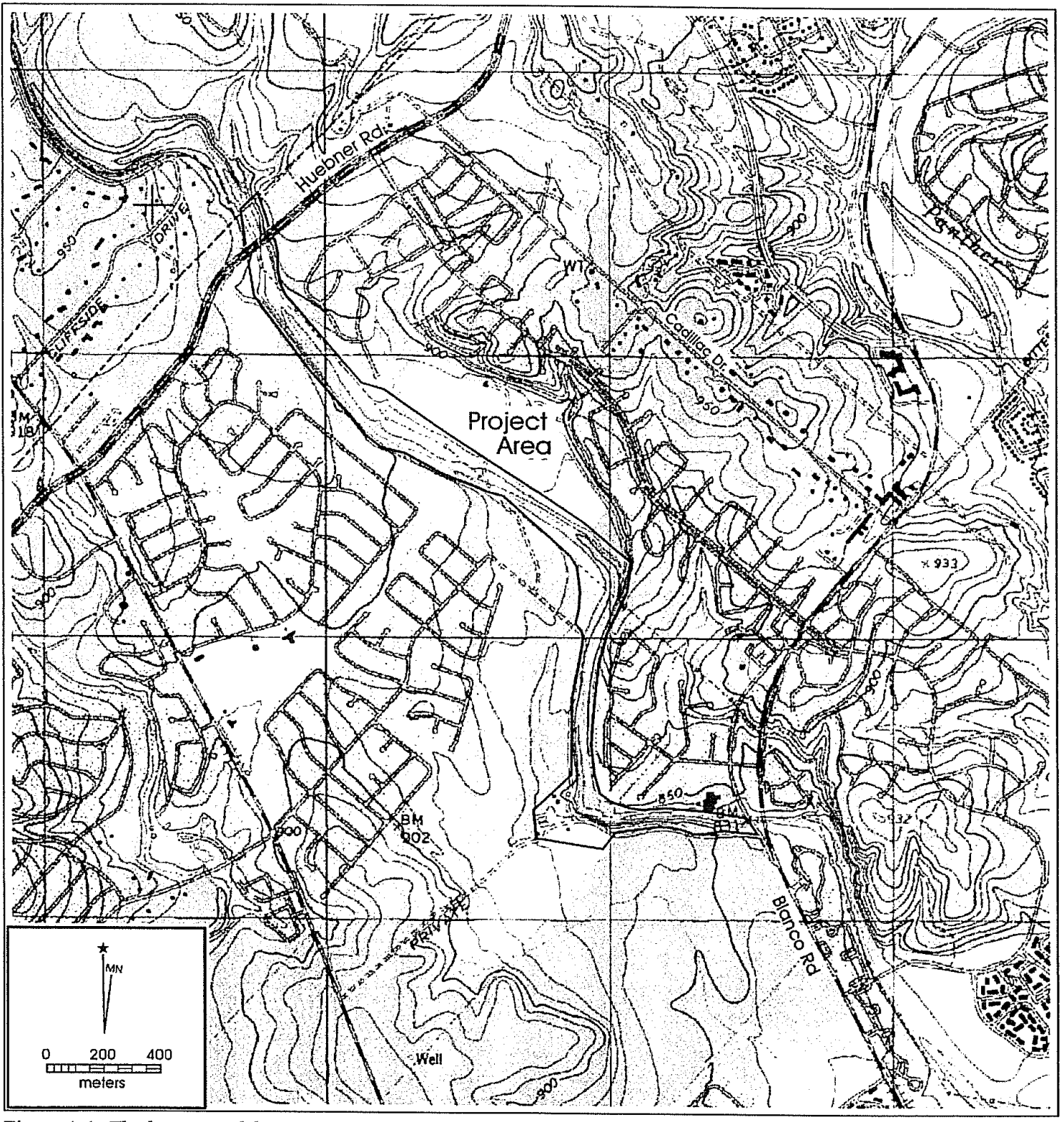

Figure 1-1. The location of the project area on the Castle Hills 7.5-minute series USGS quadrangle map. 
Golondrina, Meserve, and Scottsbluff, are diagnostic of the late Paleoindian. The marked changes in lithic technology coincide with changes in species hunted.

\section{Archaic Period}

This period spans from ca. 7000 B.C. to A.D. 800 . This culture period is distinguished by three phases: Early Archaic, Middle Archaic and Late Archaic. During the Archaic there is a shift in subsistence to a greater emphasis on the exploitation of specific local environments. Differences between phases are again marked by changes in material culture and site characteristics; for instance, the utilization of burned rock features (Weston 2003). Hunting strategies focus mainly on medium to small game. The ecological changes that occurred throughout the long span of the Archaic period could account for the changes in material culture.

\section{Late Prehistoric Period}

This period extends from ca. A.D. 800 to 1700 and is marked by the introduction of the bow and arrow. Austin and Toyah Phases distinguish this culture period. A series of distinctive traits marks the shift from the Archaic to the Late Prehistoric period, including the technological shift to the bow and arrow and the introduction of pottery. Subsistence practices remain relatively the unchanged, especially during the Austin Phase.

\section{Historic Period}

The Historic period is characterized by European contact with Native cultures in the Americas. While Spanish explorers had established their presence in Texas since the 1500s, European settlements, the Spanish in particular, became part of the Texas landscape beginning in the late $1600 \mathrm{~s}$. Mission settlements began to be established in Bexar County in 1718 beginning with Mission San Antonio de Valero (Chapa 1997). The introduction of a new culture is reflected in settlement patterns and material culture. Land within the project area (southwest portion) begins to appear in land transactions in the late 1800s (see Chapter 4: Archival Research).

\section{Previous Archaeological Investigations}

There have been numerous archaeological sites recorded in the environs of the project area along Salado Creek and nearby Panther Springs Creek as part of large archaeological survey and testing efforts conducted for Walker Ranch and Wurzbach Parkway (Fox 1979; Hudson et al. 1974; Potter et al. 1995; Tomka 1998; Weston 2003). Both Prehistoric and Historic sites are present in this area. Due to the location of the project area within the Upper Salado watershed, a desirable locale for prehistoric hunter and gatherers, there is a potential for cultural resources. According to Potter et al. (1995:10), sites encountered in the Upper Salado are typically in shallow deposits and should be discernable on the surface. Archaeological sites in close proximity to the project area are $41 \mathrm{BX} 225,41 \mathrm{BX} 844,41 \mathrm{BX} 946$ and $41 \mathrm{BX} 1063$. These sites are good examples of types that are likely to be encountered during the archaeological investigations of the project area.

Site 41BX225 is east of Blanco Road, immediately east of the project area It was documented by W. R. Hudson in 1973 and is located on the west bank of Salado Creek (Texas Historical Commission [THC] 2006). Subsurface lesting was not conducted on the site, though cultural material observed on surface consisted of primary and secondary flakes. Further work was not recommended due to the erosion and shallowness of cultural debris.

Site 41BX844 is located north of the project area, north of Huebner Road, on the east side of Salado Creek (approximately $0.10 \mathrm{mi}$. from the project area). The site was documented in 1990 by C. K. Chandler (THC 2006). At the time of its recording, numerous looter pot hol es were noted on site. Artifacts present included fire-fractured rock, and large tested chert nodules. Recommendations were not provided on the Texas Archeological Sites Atlas site form (THC 2006).

Site 4 1 BX946 is located approximately $0.24 \mathrm{mi}$. south of the project area. It was recorded by Frank Weir formerly of the Texas Department of Transportation (date unknown) as having very sparse cultural material on the surface (THC 2006). Further work was not recommended on the site due to erosion. 
Site 41BX1063 was recorded in 1994 by as part of the Wurzbach Parkway project (THC 2006; Black et al. 1998). The site is approximately $0.28 \mathrm{mi}$. southwest of the project area and since its initial recording has been impacted by residential development. The intact portion of the site measured approximately $50 \mathrm{~m}^{2}$. Shove] tests revealed that the cultural deposits ranged from 15 to 25 centimeters below surface (cmbs). Three cores were collected from the surface and lithic debitage was encountered in shovel tests. Due to the severity of disturbance and shallow deposits, further work was not recommended. 


\section{Chapter 2: Field and Laboratory Methods}

The Center for Archaeological Research of The University of Texas San Antonio was contracted by Rehler Vaughn and Koone, Inc., of San Antonio to conduct a 100 percent pedestrian survey along Salado Creek for the proposed North Salado Creek Greenway Belt project. A preliminary reconnaissance of the project area indicated that much of the ROW consisted of the active creek channel, and many areas of the ROW lacked sediments and were marked by exposed bedrock. The sediments have already been scoured by intermittent high velocity flooding episodes.

Low and high probability areas along the APEs were identified based on the degree of soil deposition evident during reconnaissance of the project area (Figure 2-1). Low probabilities areas were defined as portions of the ROW that were represented by only the creek channel and areas

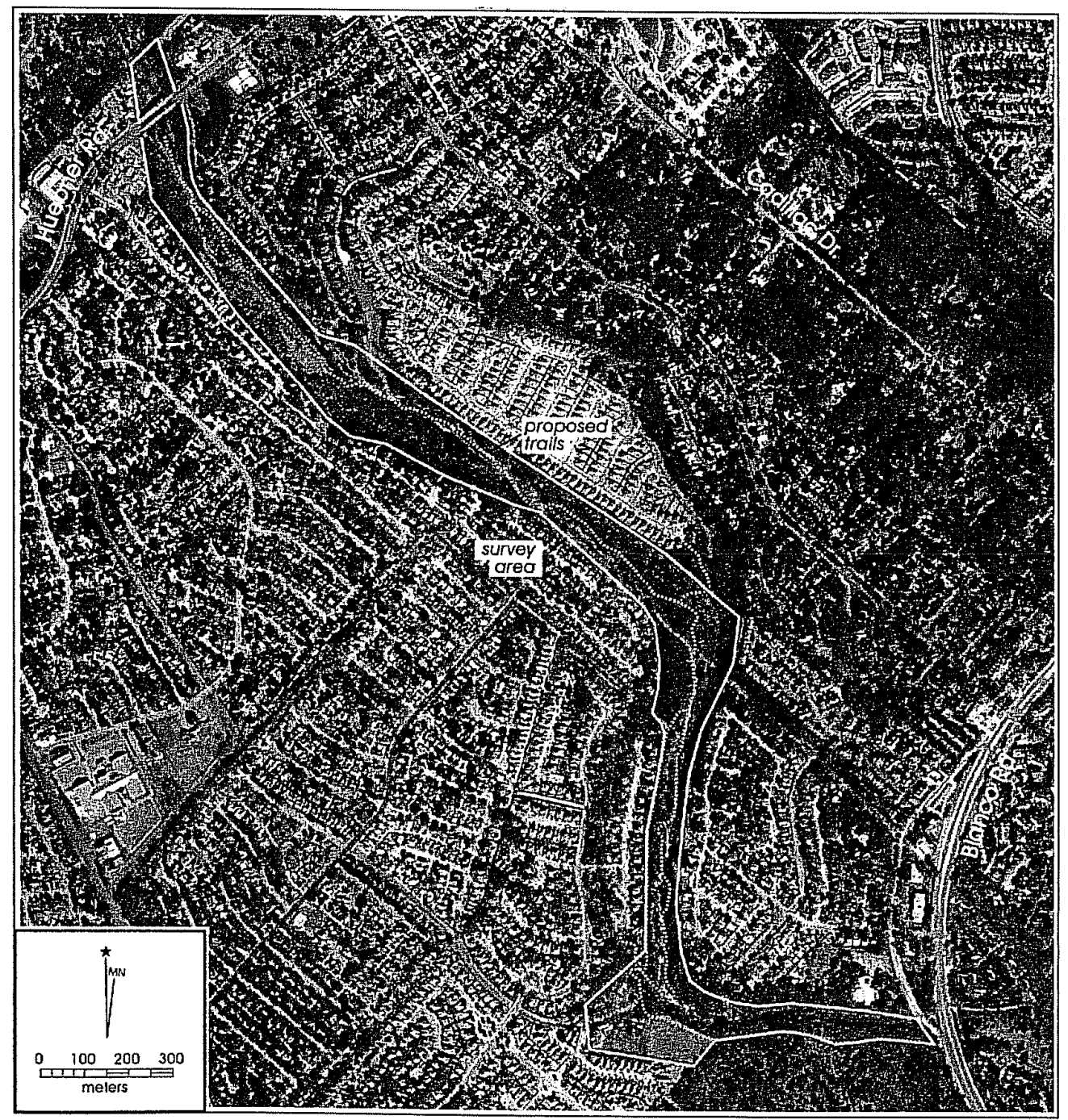

Figure 2-1. Aerial photograph of the survey areas. 
where very little sediment is evident. Though much of the project ROW has been affected by flooding and heavy scouring, there were a few areas that appeared to have sediment deposits and these areas were deemed high probability areas. Two high probability areas were identified near the central portion of the project ROW on the east bank of the creek. Both the east and west banks of the southern portion of the project ROW are high probability areas identified during reconnaissance.

A possible historical homestead (the Voelker Ranch property) was also identified during reconnaissance on the southern portion of the project ROW on the west bank of Salado Creek (Figure 2-1). Though this area is depicted as being part of the project area, no right-of-entry to the property could be secured at the time of the project to fully assess its age and condition.

Approximately 50 percent of the project area (42.5 acres) was so severely eroded by repeated high energy flooding episodes that no shovel testing was possible due to exposed bedrock and channel gravel. Additionally, right-of-entry was not gained to the nine acres of the Voelker Ranch property located in the southwest portion of the project area. Initially, we had planned to excavate a minimum of 38 shovel tests (STs), at a density of 2 STs/acre, to fulfill THC minimum survey standards. Subtracting the 42.5 acres of the project area that cannot be shovel tested, and the nine acres of land to which we did not gain access, this resulted in a total of 17 recommended shovel tests. Shovel tests were to be placed strategically in areas that exhibit some sediment. Initial review of the thickness of the deposits in high probability areas was to be determined by shovel testing when possible. If shovel testing revealed deposits in excess of $60 \mathrm{~cm}$, the areas were to be explored by backhoe trenches.

Shovel tests were $30 \mathrm{~cm}$ in diameter, and when possible, extend to a depth of $60 \mathrm{~cm}$. They were excavated in 10-cm levels, and all soil from each level was screened through 1/4-in. hardware cloth. All encountered artifacts were bagged by provenience and returned to the CAR for laboratory processing, analysis, and curation. A shovel test form was completed for every excavated shovel test. Data collected from each shovel test included the final excavation depth, a tally of all materials recovered from each $10-\mathrm{cm}$ level, and a brief soil description (texture, consistency, Munsell color, inclusions). The location of every shovel test was identified using a Trimble Geo Explorer II GPS unit. Shovel test locations also were sketched onto aerial photographs as a backup to GPS provenience information. Any additional observations considered pertinent were included as comments on the standard shovel test excavation form.

\section{Site Recording and Identification}

For the purpose of this survey, the minimum requirements for the presence of cultural materials to constitute a site are as follows: (1) five or more surface artifacts lie within a 15-m radius (ca. $706.9 \mathrm{~m}^{2}$ ); (2) a single cultural feature, such as a hearth, observed either on surface or exposed in shovel testing; (3) a positive shovel test containing at least three artifacts within a given 10 -cm level; (4) a positive shovel test containing at least five total artifacts; or (5) two positive shovel tests located within $30 \mathrm{~m}$ of each other.

Site boundaries were plotted on aerial photographs and the appropriate topographic quadrangle sheet, and location data - was collected with a GPS unit. Digital photographs were to be taken of each site. Texas site forms were to be prepared for each new site documented during the survey.

\section{Archaeological Laboratory Methods}

All cultural materials and records obtained and/or generated during the project were prepared in accordance with federal regulation $36 \mathrm{CFR}$ part 79 , and $\mathrm{THC}$ requirements for State Held-in-Trust collections. Artifacts processed in the CAR laboratory were washed, air-dried, and stored in 4-mm, zip-locking, archival-quality bags. Each label contained provenience information and a corresponding lot number written in pencil or laser printed. Artifacts were separated by class and stored in acid-free boxes. Digital photographs were printed on acid-free paper and labeled with archivally appropriate materials and placed in archival-quality sleeves. All field forms were printed on acid-free paper and were completed in pencil. If forms were soiled they were placed in archival-quality sleeves. All artifacts and documentation have been curated at CAR. 


\section{Chapter 3: Summary of Field Results}

Two days in March and an additional day in May were devoted to the pedestrian survey of the North Salado Creek Greenway Belt project area. CAR employees were joined by several volunteers from the South Texas Archaeological Association to conduct the survey. Individuals were placed two to three meters apart on both sides of the creek bed, where the creek bedrock or river gravels were not present. Shovel tests were placed in areas were soils appeared to have some depth. A total of 12 shovel tests were excavated within the project area. The terminal depths of these tests are presented in Table 3-1. Of these twelve shovel tests, six produced some cultural material. Two shovel tests produced burned rock; the other positive tests contained a mixture of historic material. The artifactual material recovered from the shovel tests is presented in Table 3-2...

Shovel Test 1 was placed on the east bank of Salado Creek, approximately three meters west from the rear fence of 13206 Stairock Street (Figure 3-1). The soil consisted of soft, sandy clay, but contained roots, river pebbles and gravel in both $10-\mathrm{cm}$ levels that were excavated. No cultural material was encountered and the shovel test was terminated at $17 \mathrm{cmbs}$ when bedrock was encountered.

Shovel Test 2 was located on the north side of a small concrete drainage behind 13201 Stairock (Figure 3-1). The shovel test was placed on the upper portion of a slight slope. The first level consisted of soft, sandy clay with gravels, and produced one fragment of modern soda bottle glass. The second level had similar soil, but the shovel test was terminated at $20 \mathrm{cmbs}$ upon finding large limestone rocks.

Shovel Test 3 was located northwest of Shovel Test 2, on the opposite side of the creek from the Voelker Ranch property (Figure 3-1). The shovel test was placed atop a small knoll that extended from the residential property. The shovel test contained a large quantity of gravels and modern material, including tar paper and glass fragments. The shovel test was terminated at $16 \mathrm{cmbs}$ upon encountering large limestone rocks.

Shovel Test 4 was located on the west bank of Salado Creek, just northeast of the private lane leading to the Voelker Ranch property. The soil was very compact, silty clay. The first level (0-10 cmbs), produced a fragment of chipped stone. The test was terminated at $25 \mathrm{cmbs}$, after encountering dense alluvial gravels.

Shovel Test 5 was located south of Shovel Test 4, adjacent to a portion of the proposed trail: A few flakes and a core were noted on the surface in the immediate area, though the shovel test itself did not produce any cultural material. No artifacts were found past Level ] $(0-10 \mathrm{cmbs})$, and the shovel test was terminated at $56 \mathrm{cmbs}$ due to the increased amount of large gravel. The area surrounding ST 4 and ST 5 was registered as a site (41BX1656) due to the surface

Table 3-1. Temination Depths and Presence/Absence of Artifacts for Shovel Tests

\begin{tabular}{|c|c|c|c|c|}
\hline Shovel Test & $\begin{array}{c}\text { Termination } \\
\text { Level }\end{array}$ & $\begin{array}{c}\text { Termination } \\
\text { Depth (cmbs) }\end{array}$ & Reason for Termination & $\begin{array}{c}\text { Presence of } \\
\text { Artifacts }\end{array}$ \\
\hline 1 & 2 & 17 & Bedrock & No \\
\hline 2 & 2 & 20 & River Gravel & Yes \\
\hline 3 & 2 & 16 & River Gravel & Yes \\
\hline 4 & 3 & 25 & River Gravel & No \\
\hline 5 & 6 & 56 & River Gravel & No \\
\hline 6 & 6 & 57 & River Gravel & No \\
\hline 7 & 2 & 20 & Root & No \\
\hline 8 & 3 & 26 & Limestone Rock & Yo \\
\hline 9 & 3 & 27 & Bedrock & Yes \\
\hline 10 & 1 & 4 & River Gravel & Yes \\
\hline 11 & 1 & 4 & Cable & Yes \\
\hline 12 & 3 & 27 & Bedrock & \\
\hline
\end{tabular}


Table 3-2. Historic Artifacts Recovered from North Salado Creek Shovel Tests

\begin{tabular}{|c|c|c|c|c|c|}
\hline $\begin{array}{c}\text { Shovel } \\
\text { Test } \\
\end{array}$ & Level & $\begin{array}{l}\text { Depth } \\
\text { (cmbs) } \\
\end{array}$ & Artfact Type & Count & Note \\
\hline 2 & 1 & $0-10$ & Brown Glass & 1 & Not collected \\
\hline 3 & 2 & $10-20$ & Brown Glass & 1 & Not collected \\
\hline 3 & 2 & $10-20$ & Tar Paper & 1 & Not collected \\
\hline 9 & 1 & $0-10$ & Green Glass & 3 & Not collected \\
\hline 9 & 1 & $0-10$ & Brown Glass & 1 & Not collected \\
\hline 9 & 1 & $0-10$ & Clear Glass & 3 & Not collected \\
\hline 9 & 1 & $0-10$ & Blue Lamp Glass & 1 & Not collected \\
\hline 9 & 1 & $0-10$ & Burned Rock & 2 & Not collected \\
\hline 9 & 1 & $0-10$ & Metal Frag & 1 & Not collected \\
\hline 9 & 1 & $0-10$ & Slate Frag & 1 & Not collected \\
\hline 9 & 1 & $0-10$ & Brick & 1 & Not collected \\
\hline 9 & 2 & $10-20$ & Brown Glass & 1 & Not collected \\
\hline 9 & 2 & $10-20$ & Clear Glass & 1 & Not collected \\
\hline 9 & 2 & $10-20$ & \begin{tabular}{|l|} 
Bottle Cap \\
\end{tabular} & 1 & Metal screw on; Not collected \\
\hline 10 & 1 & $0-10$ & Green Glass & 1 & Not collected \\
\hline 10 & 1 & $0-10$ & Brown GTass & ] & Not collected \\
\hline 10 & 1 & $0-10$ & Clear Glass & 1 & Not collected \\
\hline 11 & 1 & $0-10$ & Clear Glass & 1 & Not collected \\
\hline 11 & ] & $0-10$ & Aqua Glass & 1 & Not collected \\
\hline 12 & 1 & $0-10$ & Olive Glass & 1 & Not collected \\
\hline 12 & 1 & $0-10$ & Brown Glass & 1 & Not collected \\
\hline 12 & 1 & $0-10$ & Clear Glass & 1 & Not collected \\
\hline 12 & 1 & $0-10$ & Lamp Glass & 1 & Not collected \\
\hline 12 & 1 & $0-10$ & Burned Rock & 1 & Not collected \\
\hline 12 & 1 & $0-10$ & Bottle Cap & 1 & $\begin{array}{l}\text { Metal with aluminum lining; Not } \\
\text { collected }\end{array}$ \\
\hline Surface & Near Roaring 20s & & Metal Padlock & 1 & \\
\hline Surface & Near Roaring 20s & & Semi-porcelain & 1 & Syracuse China Econo-Rim \\
\hline Surface & Near Roaring 20s & & Clear Glass & 1 & Goblet stem \\
\hline Surface & North of Roaring 20s & & Brown Glass & 1 & Stoppered bottle \\
\hline Surface & North of Roaring 20s & & Purple Glass & 1 & \\
\hline Surface & North of Roaring $20 \mathrm{~s}$ & & Clear Glass & 1 & bottle \\
\hline Surface & North of Roaring 20s & & Brown Glass & 1 & $\begin{array}{l}\text { Neck with metal cap still in place, } \\
\text { bale and wire cap }\end{array}$ \\
\hline
\end{tabular}

lithic scatter and the presence of a possible grave. No other shovel tests were excavated in the area due 10 large limestone outcropping visible on the surface and the landform had very definite boundaries with Voelker Lane to the north, a housing development to the east, the creek bed to the south and the edge of the terrace to the west. Ownership of the possible grave is unknown.
Shovel Test 6 was located further north along on the east bank of Salado Creek (Figure 3-1). The shovel lest was placed approximately $3 \mathrm{~m}$ northeast of the landform's edge, next to a large mountain laurel tree. The shovel test location was chosen due to flakes and a core that were noted in the area on the surface. The first two levels produced burned rock. The remainder of the shovel test produced no cultural material. The shovel test was excavated to $57 \mathrm{cmbs}$. 


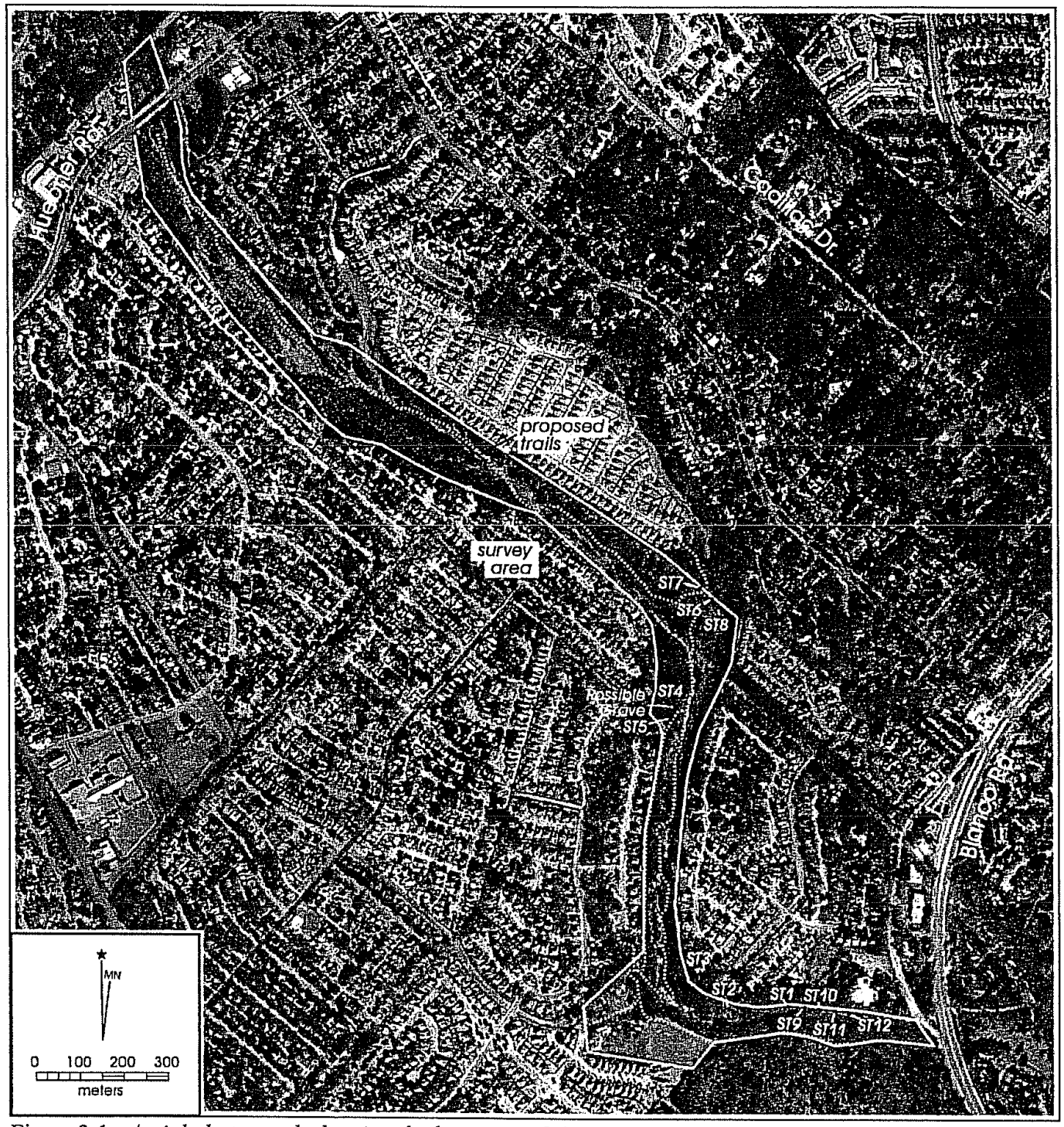

Figure 3-1. Aerial photograph showing the locations of shovel tests. 
Shovel Test 7 was placed northwest of Shovel Test 6, along the same terrace, though on opposite side of the small drainage that divides the landform. Shovel Test 7 was excavated to $20 \mathrm{cmbs}$ and was terminated due to large roots.

Shovel Test 8 was placed southeast of Shovel Test 6 , approximately $2 \mathrm{~m}$ from the end of the landform. The shovel test produced no cultural material within the three levels excavated. The test was terminated at $26 \mathrm{cmbs}$ after encountering a large limestone rock. Though Shovel Tests 6-8 did not produce significant cultural material, the quantity of surface finds indicated that the area should be deemed a site. The site was registered as $41 \mathrm{BX} 1657$, but requires additional testing.

Shovel Test 9 was located on the east bank of Salado Creek, in the southern portion of the project area. Fragments of green, brown, clear, and blue glass, and a fragment of mirror, were encountered in the first level of the test. Level 1 (0-10 cmbs) also produced fragments of burned rock, charcoal, and a small fragment of unidentifiable brick. Level 2 ( $10-20 \mathrm{cmbs}$ ) also contained clear and brown glass fragments. Two metal bottle caps were noted in the level as well. The shovel test was excavated to $27 \mathrm{cmbs}$, before hitting bedrock.

Shovel Test 10 was located just south of ST 9 , in an area that had many broken glass fragments scattered on the surface. Several modern glass fragments were noted, but the test was terminated at $4 \mathrm{cmbs}$ due to bedrock.

Shovel Test 11 was placed approximately five meters downstream from ST 10, on part of the eroding slope from the Roaring 20's property. A mixture of material was encountered including clear glass fragments, safety glass fragments, asbestos tile fragments, and plastic. The test was terminated at $4 \mathrm{cmbs}$ having encountered a large insulated cable.

Shovel Test 12 was placed approximately $3 \mathrm{~m}$ from ST 11 . The first level $(0-10 \mathrm{cmbs})$ produced glass fragments (clear, brown, olive, lamp), unidentified metal fragments, plastic, and bottle caps. Level $2(10-20 \mathrm{cmbs})$ produced no cultural material. The test was terminated at $27 \mathrm{cmbs}$ having encountered bedrock.
Within the vicinity of the Roaring 20 s, several artifacts were collected from the surface. These include a graduated brown glass bottle with a decayed cork stopper. This medicine bottle possibly dates to the early portion of the twentieth century. A fragment of very thick, purple glass was collected, which dates between the 1880s and 1920s. A rusted metal padlock was also collected from the surface, manufactured sometime before the 1950s. 


\section{Chapter 4: Archival Research}

Archival research was conducted on the historical homestead identified on the southwestern portion of the project area (Figure 4-1). Relevant records such as the Texas Archaeological Sites Atlas, CAR's research archives and historical records from the Bexar County Clerk's office were consulted to reconstruct the ownership of the property. An unpublished manuscript written by the late I. Waynne Cox documenting the history of Walker Ranch was encountered in CAR laboratory files. The document was a useful aid in reconstructing the history of the property. While the exact date of the homestead's construction is unknown, structures of similar architectural design in Bexar and surrounding counties typically date to the later half of the 1800s (Thompson and Figueroa 2005). The homestead exhibits similarities to the Naegelin property investigated in 2005 with a central wooden door flanked by wood-framed, double-hung sash windows and a front porch area (Thompson and Figueroa 2005). There was no mention of a homestead in the examined deed records pertaining to the Voelker Ranch property.

Early on, the land and the entire project area appear to have been part of a larger property. The property passed through several hands and the earliest documentation in which part of the property is mentioned is 1846 , where Sterling N. Dobie is shown as Patentee of a portion of the $1^{\text {st }}$ Class

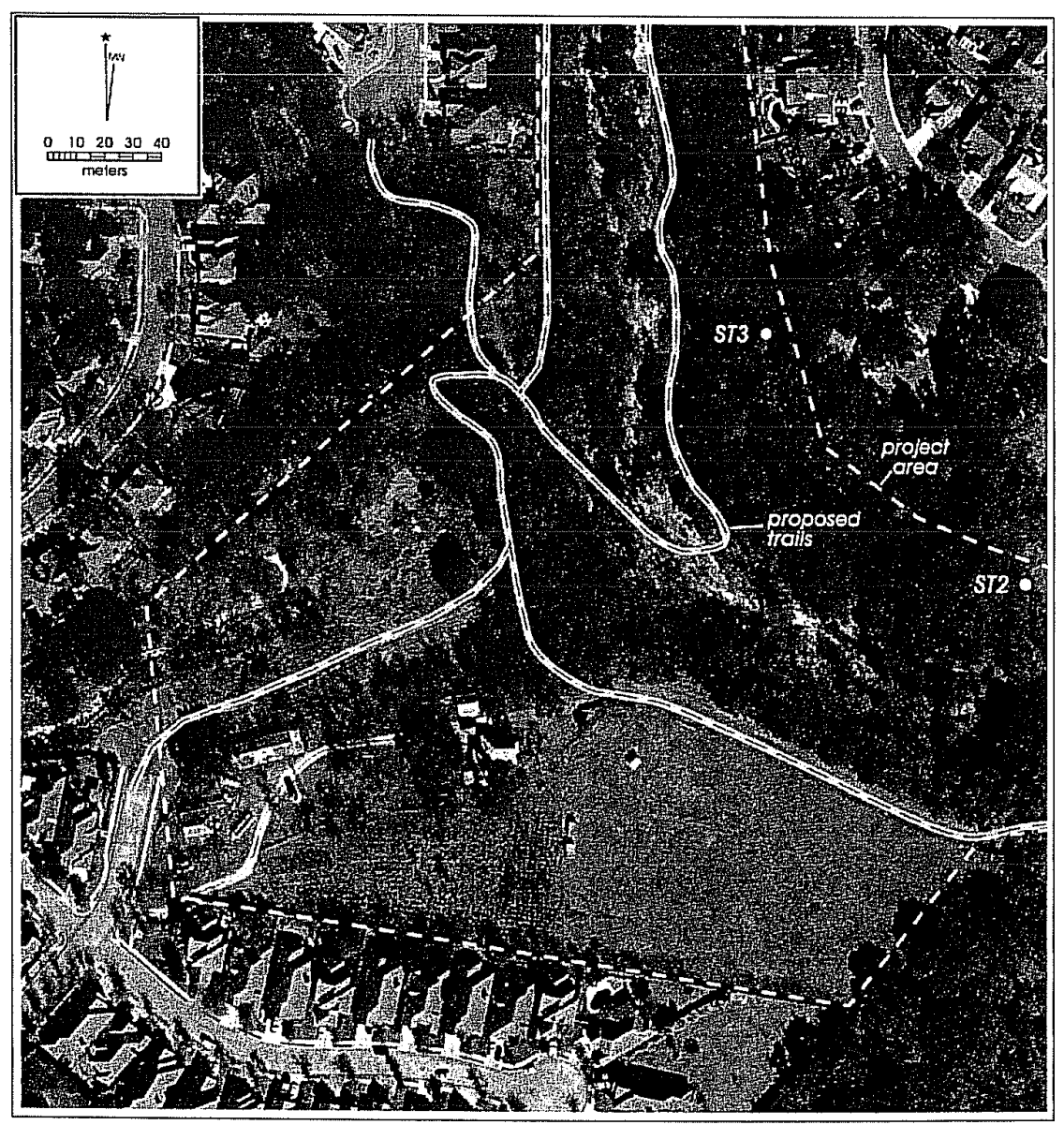

Figure 4-1. Aerial photograph of the Voelker Ranch property. 
head right land grant to James B. Thompson (Texas General Land Office [GLO] 2006a). Edward Higgins bought land that was the S. N. Dobie Survey No. 79 from Peter Odet in 1858 (Bexar County Clerk Deed Records [BCC] 2006:Book P-2, p. 631 and 652; Figure 4-2). In 1859, Higgins purchased the adjacent property, the Caldwell Survey No. 83, which was originally part of a $1^{\text {st }}$ Class head right land grant to Pinckney Caldwell (GLO 2006b; BCC 2006:Book 5189, p. 535; BCC 2006:Book 242, p. 175). The project area would have been included in the Caldwell Survey and J. B. Thompson Survey No. 84 The property on which the historic homestead is located was part of the Caldwell Survey. The Dobie, Thompson and Caldwell Surveys were quite large, approximately 1500 acres each. In 1859 Higgins mortgaged his property to Harriet Eliza Thompson (BCC 2006:Book R-1, p. 652). After the death of Thompson, the land was passed to heir Jennie Ganahl in 1874. Jennie and her husband Charles Ganahl divided the land into fifty equal lots, selling off six of the lots (Cox n.d.).

In 1897, Jennie's husband sold the land to his sister Charlissa G. Walker (BCC 2006: Book 166, p. 26). At this time the property consisted of 2556 acres, with 28 lots being from the Caldwell Survey. The land was conveyed to the son of Charlissa G. Walker, Chas G. Walker, in 1905 (BCC 2006: Book 242, p. 175). Nat Washer obtained the land in 1907 from Chas Ganahl Walker. At this time the land parcel did not consist of the entire 2556 acres as it originally started, but only 881.18 acres from the Caldwell survey (BCC 2006: Book 264, p. 283). In March of 1936 Jay B. Washer (executive of the Nat M. Washer estate) conveyed all 881.18 acres of the land, with additional tracts, to Mannie Goldsmith and others (BCC 2006: Book 1527, p. 204).

Max H. Voelcker obtained the property in 1936 from Mannie, Nat and Ruth Goldsmith (BCC 2006: Book 1541, p. 164). By this time, only two hundred acres remained of the Caldwell Survey. Max H. Voelcker and his heirs continued to possess the property. Minnie Voelcker was appointed the executrix of the Estate of Max H. Voelcker. Max H. Voelcker is buried at the Coker Cemetery (Texas.i-found-it.net 2006).

Two owners of the property held on to the land for long periods. Nat M. Washer had the property from 1907 to 1936. Max Voelcker and heirs held on to the land from 1936 until recently. Though it seems logical that the homestead was built while the property was being owned by Nat M. Washer or Max Voelcker, the architectural elements of the homestead signal it was built prior to 1907. German style homes of this nature that were constructed of cut limestone or sandstone began to appear in Texas around 1850 (Jordan 2005). The terminal date of this architectural style is not definite, but one would assume sometime during the first decade of the 1900s. Therefore, the homestead in question would have been constructed while the property was in the hands of Harriet Thompson, Jennie de Ganahl, or perhaps Nat M. Washer.

Additional research was conducted on a piece of property located in the southern portion of the project area. Currently, the remains of the Roaring 20s occupy the space to the east of the APE. At the time of the initial survey, bottles, ceramic, metal fragments, and other material were washing down the bank of the creek from the establishment. Local rumors had indicated that the structure had posed as a gambling hall, speakeasy and possibly a brothel at different points in its existence. Archival research was undertaken to determine the prior ownership of the property, as well as the function of the building over time. The property is presently owned by Honigblum Corporation of San Antonio. The property was released to the corporation in January 2006 by the Herman Management Trust Agreement, comprised of the heirs of Larry Herman (BCC 2006:Book 11893 , p. 525). Larry Herman had purchased the property in 1961, and changed the name of the establishment to the "Roaring 20s" (Padilla 1998). The club, itself, had been established in 1926 as the Shadowland Night Club. The club had been credited with being a speakeasy, a gambling hall, a meeting place for gangsters, and a showcase for big band and swing music. During the construction of the original building, the property was in the possession of William McKinney. The McKinney family had possession of the property until transferring it to James B. Hunt in the 1950s (BCC 2006: Book 4243, p. 298; Book 2833, p. 28).

The dancehall was often raided during the late 1920s and early 1930s, as it sold liquor during the prohibition era, and was frequented by unsavory patrons. The Shadowland Night Club headlined such acts as Don Albert and His Swing Band, Troy Floyd and his Shadowland Orchestra (Cullum 2006), and Duke Ellington (Hernandez 1999).

The night club was in existence for approximately 72 years, closing its doors in 1998 after failing to pass a building inspection. The structure lies on the east bank of Salado Creek and has been subjected to flooding over the years. At the time of the survey, the portion of the building closest to the bank is falling to pieces (Figures 4-3 and 4-4). Future plans for the structure are unknown, but the property was undergoing clearing during the survey. 


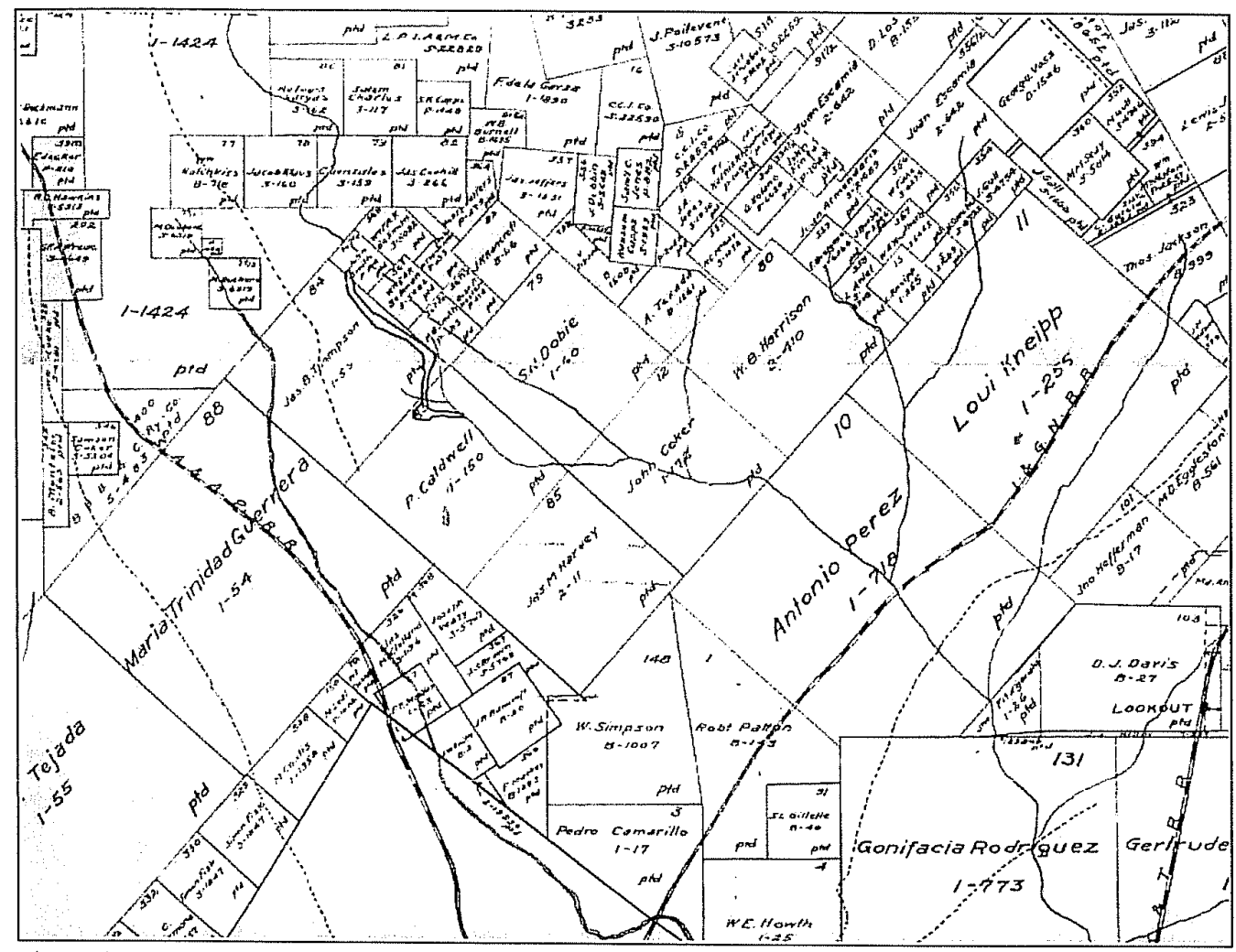

Figure 4-2. Map showing the Thompson (No. 84), Caldwell (No. 83) and Dobie Surveys (No. 79), and the project area in red. From GLO 1932.

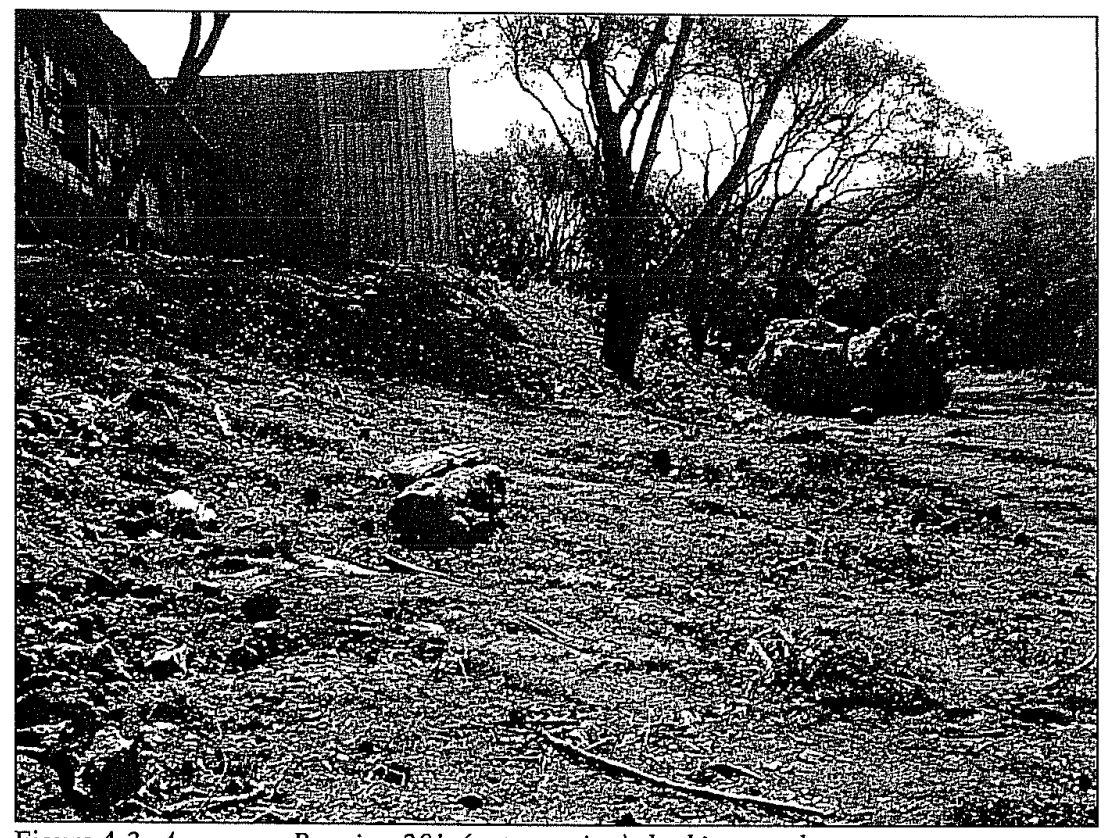

Figure 4-3. Area near Roaring 20's (note erosion), looking south. 


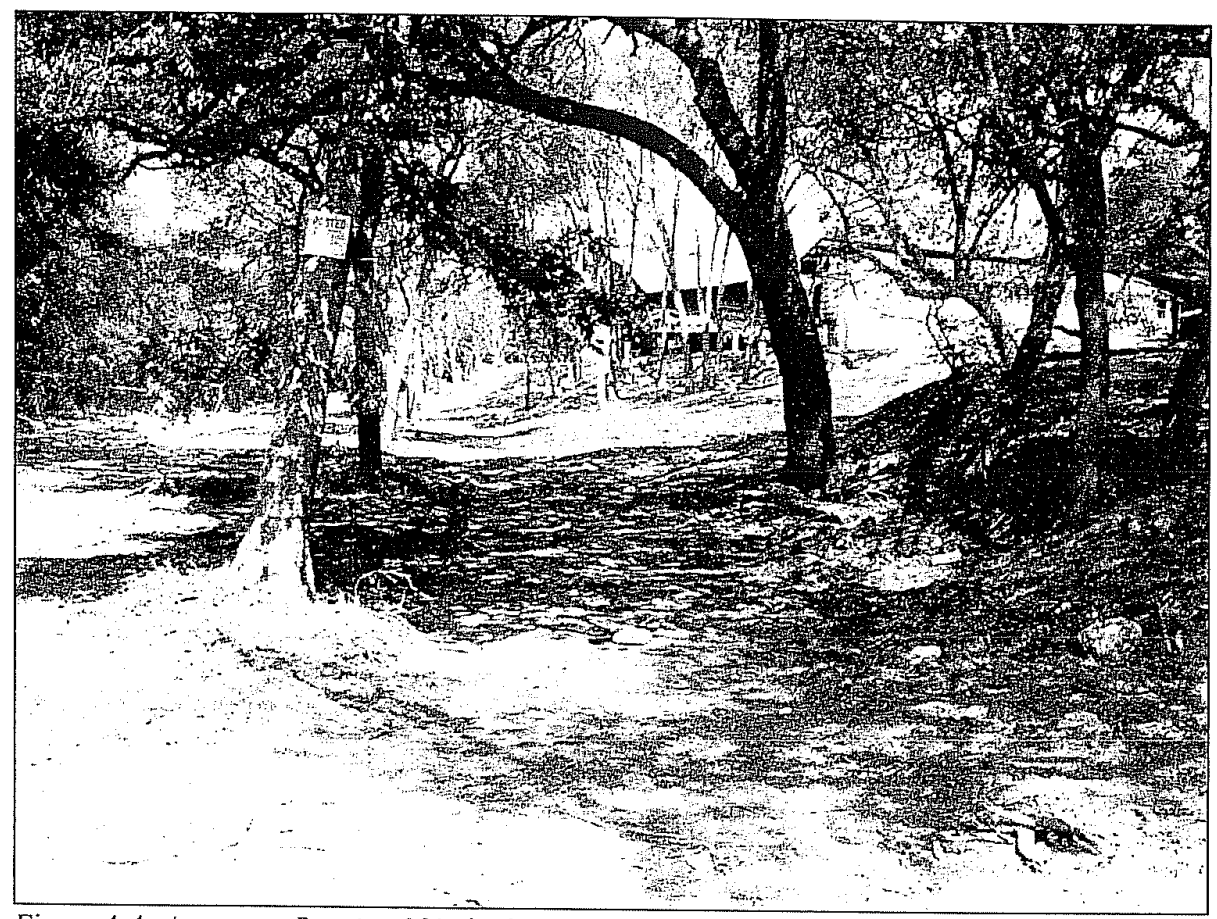

Figure 4-4. Area near Roaring 20 s, looking north. 


\section{Chapter 5: Summary and Recommendations}

A 100 percent pedestrian survey was conducted of the portion of the APE to which right-of-entry was secured. During the course of the survey, three areas of concern were identified in terms of sites that will potentially be impacted by the proposed trail system. The first area of concern (Area 1) is the current Voelker Ranch property (Figure 5-1). Investigations were not conducted on the property at the present time due to the fact that it is still under private ownership. Archival research was conducted to determine the historical background of the area. In addition to possessing a probable historic homestead, the property has the potential for producing prehistoric sites due to its location atop a terrace overlooking the Salado Creek.

Area 2, located north of the Voelker Ranch (Figure 5-1), has been determined to be a multicomponent site (41BX 1656) with a prehistoric component of unknown age and a possible late nineteenth to mid-twentieth century burial. The site is approximately 1.5 acres. The site surface contains a prehistoric lithic scatter of unknown temporal affiliation consisting of flakes and cores, with no shovel tests producing buried prehistoric cultural material (Figure 5-2). Further shovel testing of the site was not possible due to the shallow soils, with large limestone rocks exposed on the surface throughout the area. A possible grave was encountered at this site. The dimensions of the rock pile were $6 \mathrm{ft} .7 \mathrm{in}$. in length, and approximately $3 \mathrm{ft}$. across. The possible grave consists of large limestone rocks placed in a rectangle bordered by what appears to be wooden fence rails. One limestone rock is tilted on its side, appearing to be a headstone (Figure 5-3). The location of the possible grave falls within the eastem comer of the J. B. Thompson Survey No. 84. Archival research indicates that the property was conveyed to Louis Volcker (Voelker) in 1890 by Ida H. Smith (BCC 2006:Book 65, p. 607), who had obtained the property in 1885 from "WM" (William?) A. Smith (BCC 2006:Book 37, p. 576). Deed records indicate that George and Max Voelker may have been utilizing the property until 1941 when it appears that it, along with additional acreage, was conveyed to Louis in 1939 (BCC 2006:Book 1809, p. 410). At this time, the temporal and familial affiliation of the possible grave is unknown.
Area 3, approximately 0.26 acres in dimension, is located upstream of Area 2 and has been registered as site 41BX1657 (Figures 5-1 and 5-4). A narrow portion of the Salado Creek terrace is within the project boundary and produced a prehistoric surface lithic scatter of unknown age (Figure 5-5) as well as one positive shovel test. No diagnostic artifacts were recovered from the site. The site appears to extend outside of the project boundary, covering the majority of the landform. A cursory scan of the surface outside of the project boundary noted bifaces, cores, burned rock, and debitage. Approximately five pot holes were observed along the terrace, indicating probable past looting of the site. The terrace drops sharply to the creek bed below, and is crossed by a drainage that originates from the residential area to the northeast. Markings for the proposed trail and tree tags extended past the project boundary as well. The terrace of Area 3 contained deep soil deposits, although the portion of the terrace that is within the project ROW is very narrow and no additional subsurface investigations are feasible. Should additional land be acquired for the trail system outside of the current APE, further testing should be done to determine the extent of the site.

The remainder of the APE was surveyed closely, though no additional shovel testing occurred due to the rocky nature of the project area. Bedrock was exposed throughout the APE. Areas that did not have exposed bedrock often were characterized by large limestone rocks and boulders exposed on surface. The path of the trail often is placed within the current creek channel, or along an existing trail skirting the power line towers present in the northern portion of the project area. A sewer line has also been placed within the creek bed, evidence of which is marked by manholes throughout the APE.

The majority of the artifacts encountered during the course of the project were recovered in the area of the Roaring $20 \mathrm{~s}$ nightclub. The artifacts encountered in the area are consistent with what one expects to find at this type of establishment: broken glass fragments from bottles and glasses, and broken ceramic "hotel ware" typical of businesses that serve food. The range of dates that the artifacts indicate are consistent with the dates of the former night club. 


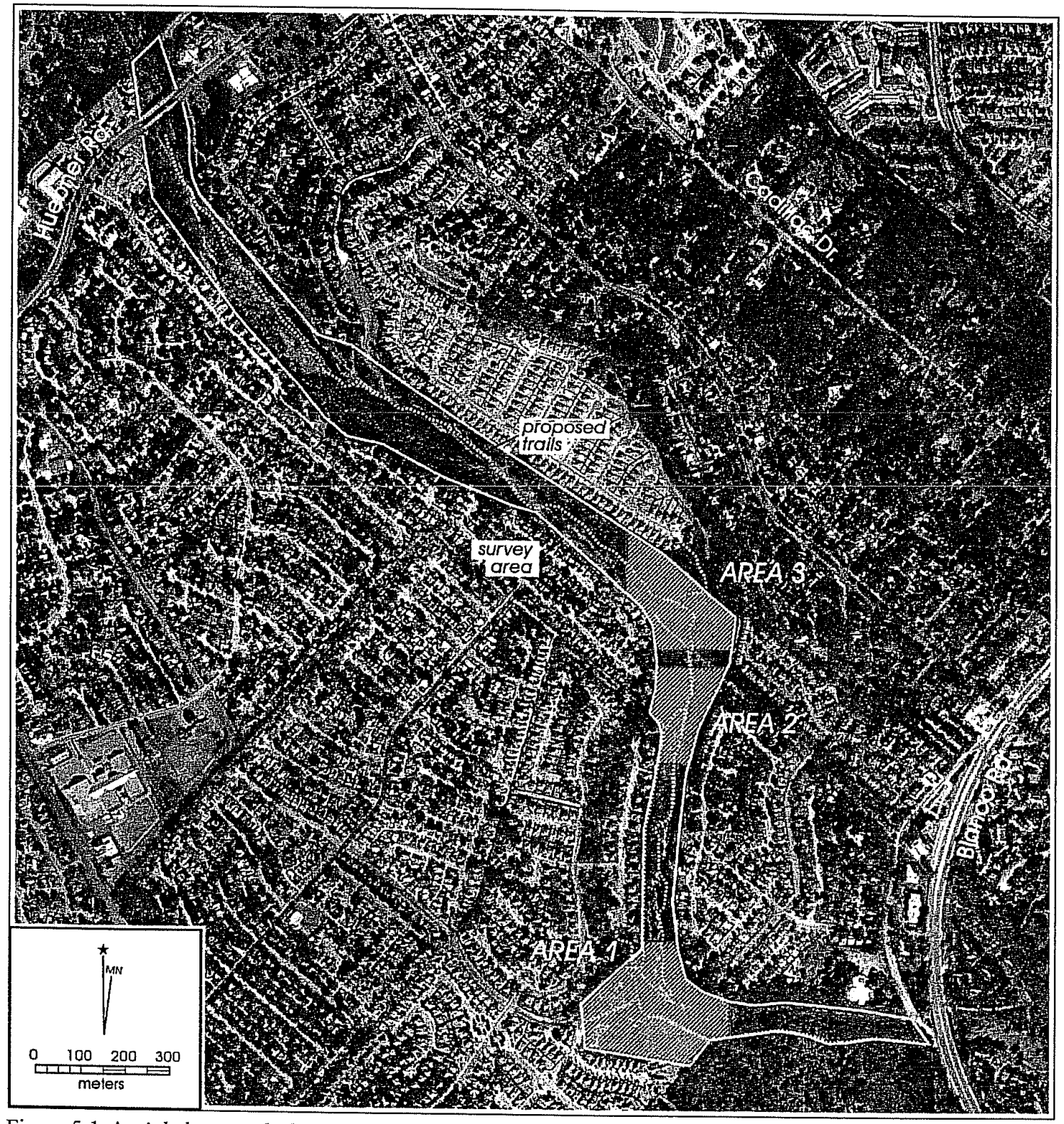

Figure 5-1. Aerial photograph showing areas of concern (Areas 1,2 and 3). 


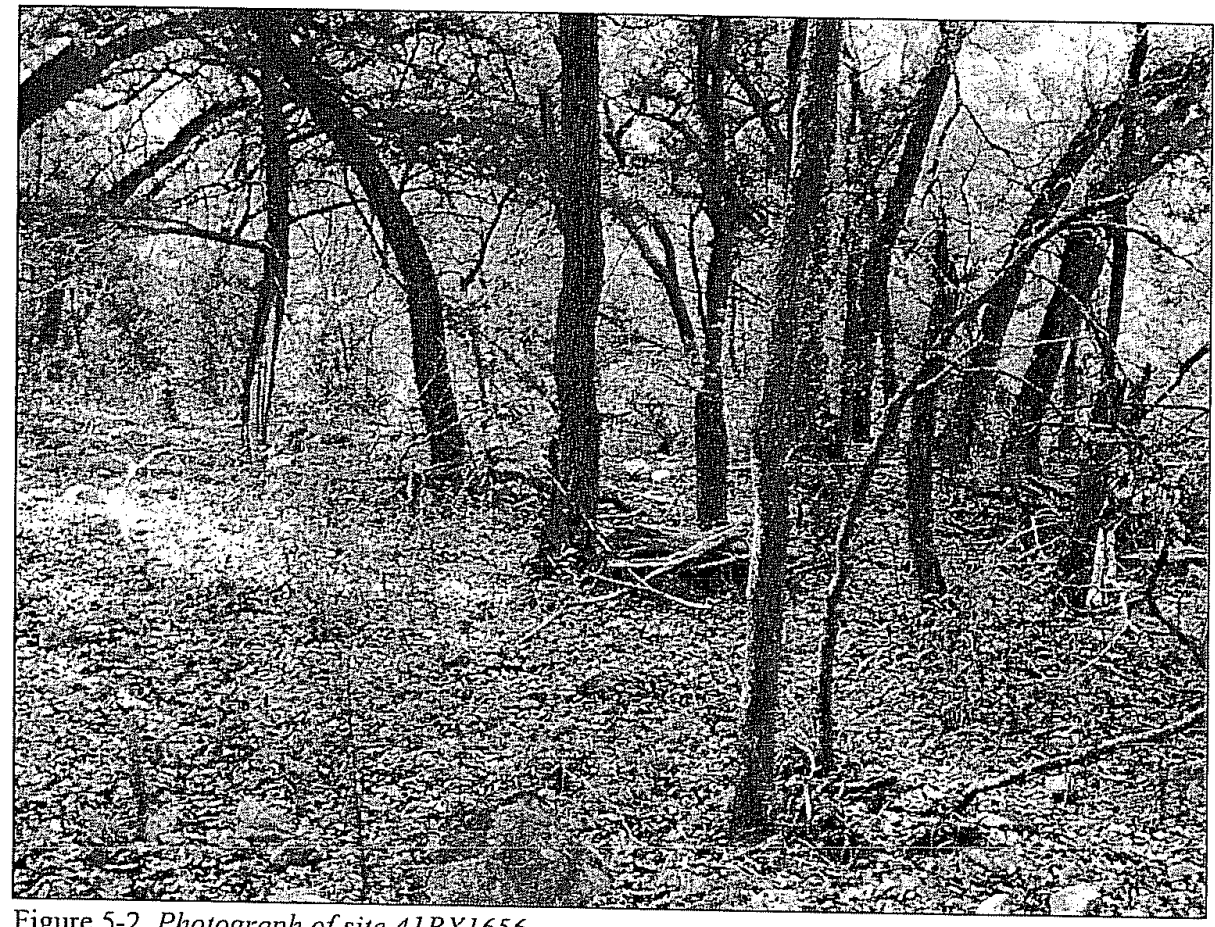

Figure 5-2. Photograph of site $41 B \times 1656$.

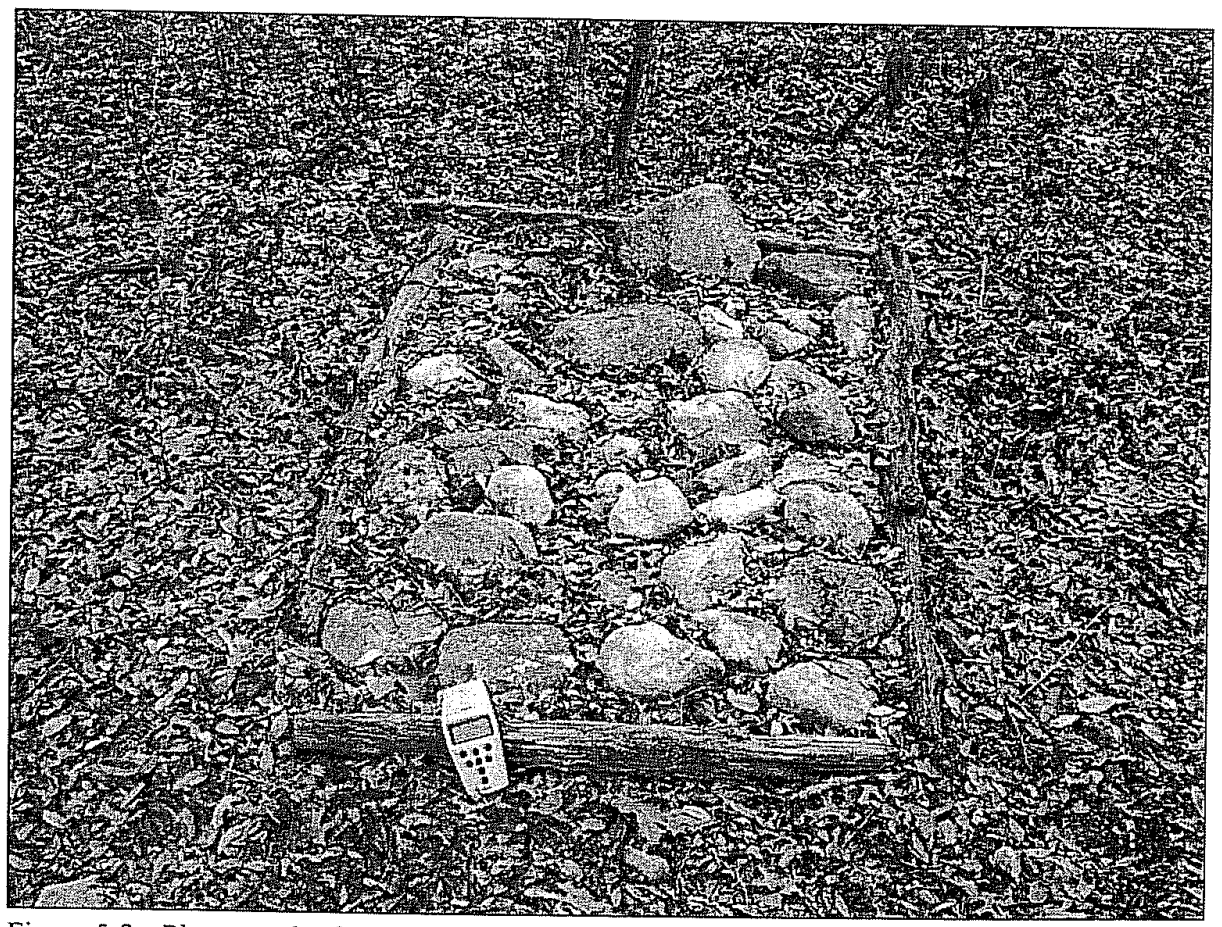

Figure 5-3. Photograph of possible grave at 41BX1656. 


\section{Recommendations}

The survey conducted in March of 2006 resulted in the documentation of two archaeological sites: 41BX1656 and 41BX1657. The immediate area of the Voelker Ranch was not investigated at the close of this project. If and when the City of San Antonio comes into possession of the property, it is recommended that intensive survey of the property be conducted. The archival background and the setting of the property indicate a high probability of encountering intact and significant prehistoric and historical cultural deposits. The property itself has been tied to several prominent figures of the history of Texas, as well as the Civil War. The pasture land of the property abuts Salado Creek, and the higher elevation of the area has potential for producing deep soils with buried, intact cultural deposits.

Site $41 \mathrm{BX} 1656$ will be bisected by one of the proposed trails. Though the prehistoric component of the site consists of an ephemeral lithic scattering, the trail would pass within viewing distance of the possible grave. More in-depth research of the land ownership may give insight to the age and family ownership of the possible grave. If additional archival research does not clarify the nature of the stone pile, it may be necessary to conduct archaeological research to define whether it truly is a grave. If it is revealed that the feature is truly a grave, care must be taken to ensure its safety. Moving the path of the trail away from the grave may aid in its protection.

Site $41 \mathrm{BX} 1657$ has not been fully investigated at the close of this project. Only a small corner of the site falls within the APE as shown on the maps provided to CAR. The site appears to extend into the private property to the east. The path of the trail system, as it is flagged in the field, is to extend into the private property outside of the mapped project boundary therefore potentially impacting portions of $41 \mathrm{BX} 1657$. It is recommended that if additional property is purchased outside of the currently mapped ROW, the site boundaries within the new ROW be established through additional fieldwork. If the proposed trail cuts across the site boundaries, we would recommend relocating the trail outside or away from the site limits if available ROW permits.

The remainder of the APE falls on shallow, eroded soils which are so thin that they do not have buried cultural

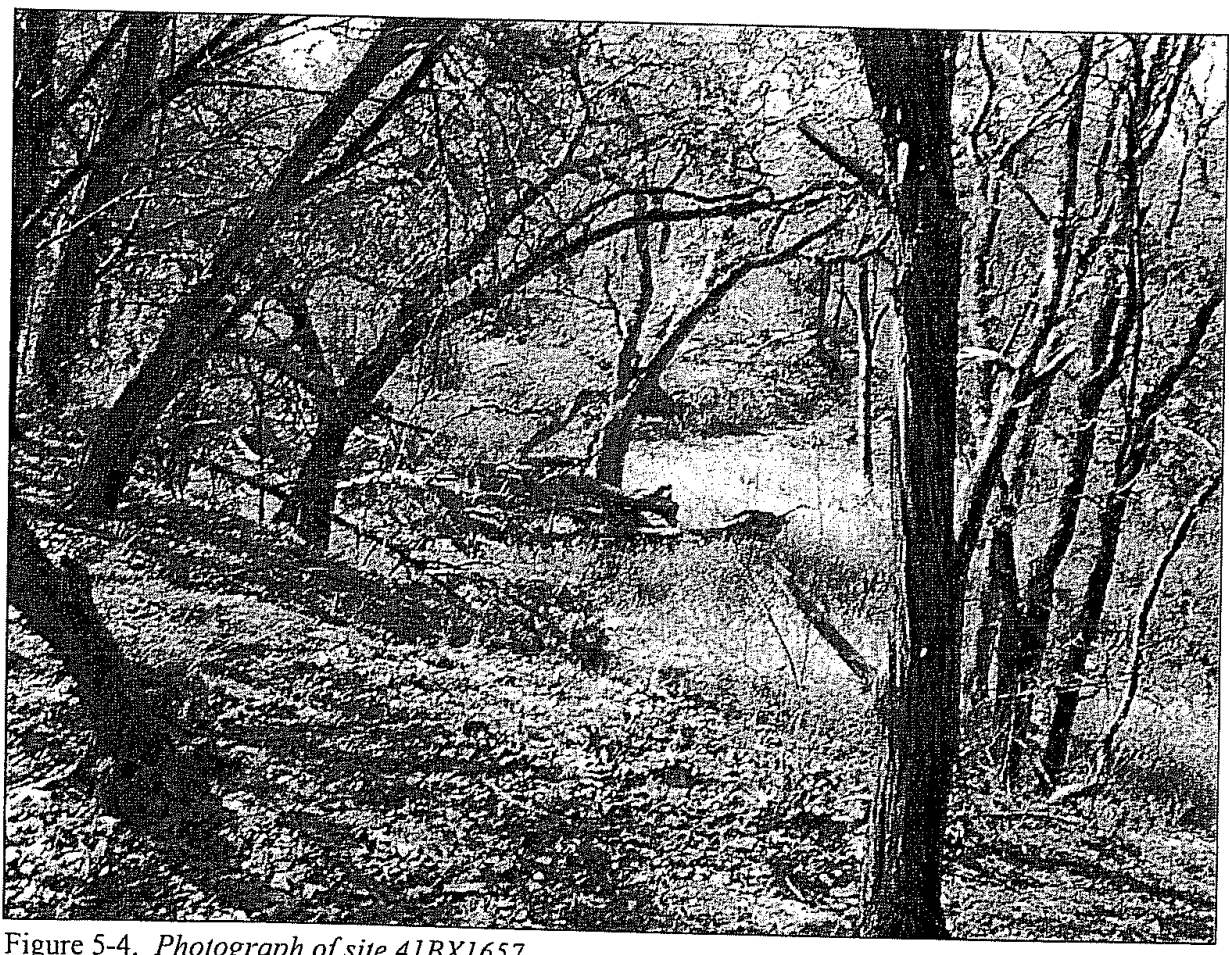

Figure 5-4. Photograph of sile 41BX1657. 


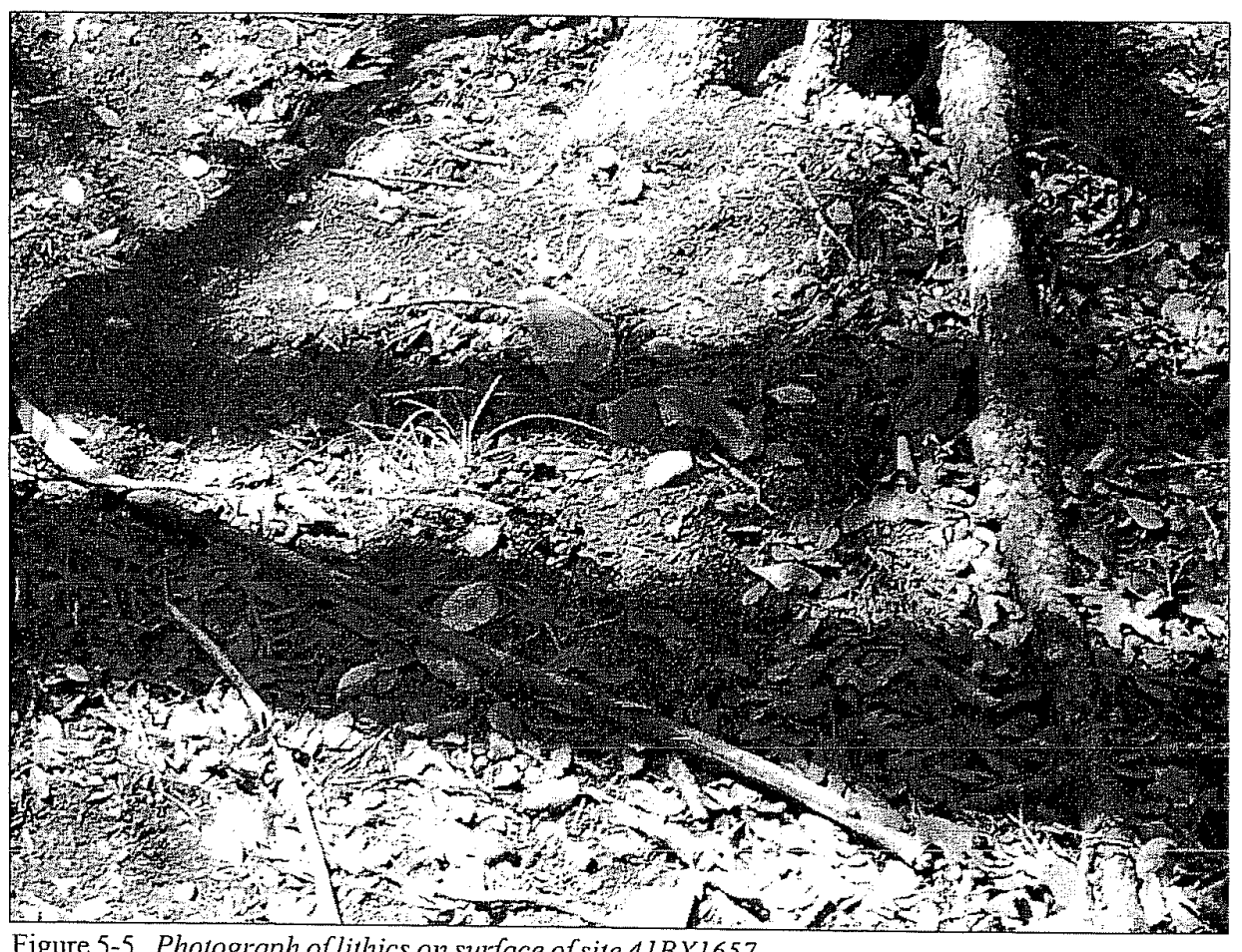

Figure 5-5. Pholograph of lithics on surface of sile $41 B X 1657$.

deposits. The trail system appears to follow trails that are already utilized by local residents at this time. The work that will be needed to create and maintain the trails will have little effect on the cultural history of the North Salado Creek. Therefore we recommend that the installation of the proposed trail system proceed as planned in the remainder of the APE. 


\section{References Cited}

Bexar County Deed Records [BCC]

2006 Deed and land records of Bexar County, Bexar County Clerk. Electronic database, <http://www.countyclerk. bexar.landata.com/>, accessed June 2006.

Black, S. L., and J. McGraw

1985 The Panther Springs Creek Site: Cultural Change and Continuity within the Upper Salado Creek Watershed, South-Central Texas. Archaeological Survey Report, No. 100. Center for Archaeological Research, The University of Texas at San Antonio.

Black, S. L., K. Jolly, C. D. Frederick, J. R. Lucas, J. W. Karbula, P. R. Taknac, and D. R. Potter

1998 Archaeology along Wurzbach Parkway, Module 3. Imvestigations and Experimentation at the Higgins Site (41BX184). Vol. 1. Studies in Archeology 27. Texas Archeological Research Laboratory, The University of Texas at Austin.

Chapa, J. B.

1997 Historia del Nuevo Reino de Leon. In Texas and Northeastern Mexico, 1630-1690, edited by J. Bautista Chapa and W. C. Fosier, p. 91. Translated by N. F. Brierley. University of Texas Press, Austin.

Cliff, M. B., M. Brown, D. E. Peter, S. N. Allday

1990 Cultural Resources Survey along Salado Creek, Bexar County; Texas. Miscellaneous Report of Investigations No. 17. Geo-Marine, Inc., Plano, Texas.

Cox, l. W.

n.d Walker Ranch-History. Manuscript on file, Center for Archaeological Research, The Unjversity of Texas at San Antonio.

Cullum, J., Jr.

2006 Satchmo and Don Albert in 1968. Electronic document, <ht1p://www.landing.com/profiles/ satch68.htm>, accessed June 2006.

Fox, A. A.

1979 Archaeological and Historical Investigations at 41BX180, Walker Ranch, San Antonio, Texas: Phase 1. Archaeological Survey Repor1, No. 83. Center for Archaeological Research, The University of Texas at San Antonio.

Hernandez, R.

1999 Stompy Jones. Electronic document, <http://weeklywire.com/ww/05-03-99/austin_music_feature1.html>, accessed June 2006.

Hudson, W. R., W. M. Lynn and D. S. Scurlock

1974 Walker Ranch: An Archaeological Reconnaissance and Excavation in North Bexar County, Texas. Office of the State Archeologist, Report 26. Texas Historical Commission, Austin. 
Jordon, T. G.

2005 German Vernacular Architecture. The Handbook of Texas Online, electronic database, <http://www.tsha. utexas.edu/handbook/online/articles/view/GG/cbgl.html>, accessed March 2006.

Padilla, G.

1998 Down to the last dance? Owners trying to keep alive old speakeasy. San Antonio Express News, 20 March, 1998. San Antonio, Texas.

Potter, D. R. and S. L. Black, and K. Jolly

1995 Archaeology along the Wurzbach Parkway, Module 1: Introduction, Conceptual Framework and Contexts of Archaeological Investigations in Bexar County, South-Central Texas. Studies in Archeology 17, Texas Archeological Research Laboratory, The University of Texas at Austin.

Taylor, F. B., R. B. Hailey and D. L Richmond

1962 Soil sumey of Bexar County, Texas. United Statès Depärtment of Agriculture, Soil Conservation Service, Washington, D.C.

Texas General Land Office [GLO]

1932 Map of Bexar County, traced from original manusçript. Scale=2000 vara: ] inch. Blue line print, portions by hand and Xerox. Compiler and draftsmen W. K. Boggs and J. Bascom Giles.

Texas General Land Office [GLO]

2006a Land Grant Search. Electronic database, <http://wwwdb.glo.state.tx.us/central/LandGrants/landgrants. cfm?intlD=148713>, Abstract No. 740, accessed June 2006

$2006 \mathrm{~b}$ Land Grant Search. Electronic database, <http://wwwdb.glo.state.tx.us/central/LandGrants/LandGrants cfm?intlD=148094>, Abstract No. 124, accessed June 2006.

Texas Historical Commission

2006 Texas Archeological Sites Allas. Electronic database, <http://nueces.thc.state.tx.us/>, accessed March 2006.

Texas.i-found-il.net

2006 Coker Cemetery, San Antonio, Texas. Electronic database, <http://texas.i-found-it.net/cokercem.html>, accessed May 2006.

Thompson J. L. and A. L. Figueroa

2005 Archaeological Survey and Archival Research of the Naegelin Tract (41BX1600) in San Antonio, Bexar Count, Texas. Archaeological Survey Report, No. 354. Center for Archaeological Research, The University of Texas at San Antonio

Tomka, S.A.

1998 An Archaeological Survey of Walker Ranch Park, Bexar County; Texas. Archaeological Survey Report, No. 282. Center for Archaeological Research, The University of Texas at San Antonio.

Weston, J. D.

2003 Archaeological Surney and Geoarchaeological Investigations at 41BX1271, Walker Ranch Park, Bexar County, Texas. Archaeological Survey Report, No. 337. Center for Archaeological Research, The University of Texas at San Antonio. 